\title{
KONSEP MODIFIKASI UNTUK MENINGKATKAN DAYA MESIN SEPEDA MOTOR
}

\section{MODIFICATION CONCEPT TO IMPROVE THE POWER OF MOTORCYCLE ENGINE}

\author{
Nirmala Adhi Yoga Pambayun ${ }^{1}$, Sukoco $^{2}$, Wardan Suyanto ${ }^{3}$, Sudarwanto ${ }^{4}$ \\ Pendidikan Teknik Otomotif FT UNY \\ E-mail: nirmalaadhi_yp@uny.ac.id
}

\begin{abstract}
ABSTRAK
Penelitian ini bertujuan untuk, (1) Mengetahui peningkatan daya mesin sepeda motor 4 langkah dengan sistem bahan bakar karburator setelah dimodifikasi, (a) volume mesin (cc); (b) perbandingan kompresi mesin; (c) mekanikal katup; (d) sistem pemasukan (intake); (e) sistem pembuangan (exhaust); (2) Mengetahui emisi gas buang mesin setelah dimodifikasi apakah masih masuk dalam ambang batas emisi yang ditetapkan pemerintah. Penelitian ini merupakan penelitian research and development. Subjek penelitian ini adalah mesin sepeda motor 4 langkah dengan sistem bahan bakar karburator. Alat yang digunakan untuk mengumpulkan data adalah dynotest dan exhaust gas analyzer. Data hasil pengujian dianalisis dengan statistik diskriptif berupa rata-rata dan persentase (\%) serta regresi sederhana. Hasil penelitian menunjukkan, (1) Daya mesin meningkat sebesar $151 \%$ dari 5,8 HP/6063 rpm menjadi 14,6 HP/10.171 rpm; (2) Emisi gas buang mesin setelah modifikasi masih masuk dalam ambang batas emisi yang ditetapkan pemerintah yakni HC 815 ppm dan CO 3.306 $\%$ dengan ambang batas HC 2400 ppm dan CO $5.5 \%$.
\end{abstract}

Kata Kunci: Modifikasi, Daya, Emisi

ABSTRACT

This studi aims to, (1) Know the power improvement of four stroke engine with carburetor fuel system after modification of, (a) engine capacity (cc); (b) compression ratio; (c) valve mechanical systems; (d) intake system; (e) exhaust system; (2) Know the exhaust gas emission level compared with maximum emission level from the government.This study was included into research and development. Subject of this study was four stroke motorcycle engine with carburetor fuel system. Data was collected by dynotest dan exhaust gas analzser. Data was analyzed by discriptive statistic as mean and percetage (\%,) and simple regression.The result of this study showed that (1) The improvement of engine power is $151 \%$, from 5,8 HP/6063 rpm into 14,6 HP/10.171 rpm; (2) The exhaust gas emission after the engine modification is lower than the rule of maximum emission level from the government, HC 815 ppm and CO $3.306 \%$ with the rule of maximum emission level are HC 2400 ppm dan CO 5.5 $\%$.

Keyword: Modification, Power, Emission

\section{PENDAHULUAN}

Kendaraan bermotor merupakan komponen yang sangat penting dalam menunjang mobilitas manusia. Kebutuhan mobilitas masyarakat untuk dapat berpindah dari satu tempat ke tempat lain yang semakin meningkat, menyebabkan kebutuhan akan kendaraan bermotor juga semakin tinggi. Diantara jenis kendaraan yang ada, sepeda motor memiliki angka pertumbuhan yang paling tinggi dan cukup pesat. Berdasarkan data dari BPS pada tahun 2009 sebesar 52.767.093 unit dan pada tahun 2013 jumlahnya sudah meningkat menjadi 84.732 .652 unit (www.bps.go.id). Hal ini disebabkan karena jenis kendaraan ini mampu melayani mobilitas pada kondisi jalan yang sempit, atau dalam kondisi lalu lintas yang padat dengan lebih baik dibandingkan dengan jenis kendaraan yang lebih besar. Selain dikarenakan harganya yang lebih terjangkau untuk berbagai lapisan masyarakat.

Meningkatnya jumlah sepeda motor juga diikuti oleh kebutuhan untuk peningkatan performa,sertapeningkatanpermasalahan yang ditimbulkan oleh membeludaknya jumlah sepeda motor. Saat ini masyarakat lebih menyukai kendaraan dengan performa yang 
mumpuni dan ditunjang dengan konsumsi bahan bakar yang efisien. Oleh karena itu, dalam mempromosikan produknya kedua hal tersebut selalu ditonjolkan dan selalu ditingkatkan oleh produsen untuk meningkatkan angka penjualannya. Permasalahan yang ditimbulkan dari meningkatnya jumlah sepeda motor yang luar biasa adalah meningkatnya polusi udara yang ditimbulkan dari emisi gas buang yang dihasilkan, kemacetan dan jumlah kecelakaan yang semakin meningkat. Untuk mengatasi dan meminimalisir permasalahan tersebut pemerintah semakin memperketat regulasi mengenai standar emisi gas buang, serta regulasi yang berhubungan dengan keamanan dan keselamatan.

Teknologi pada sepeda motor semakin berkembang dari waktu ke waktu untuk memenuhi tuntutan regulasi dan kebutuhan konsumen. Pengembangan yang dilakukan oleh produsen otomotif banyak dilakukan pada area mekanik mesin, sistem kelistrikan dan sistem bahan bakar dari kendaraan. Teknologi yang ada sudah banyak dikendalikan dengan rangkaian elektronika untuk meningkatkan keakuratan dan pengontrolan yang lebih baik. Sebagai contoh saat ini hampir semua sepeda motor keluaran terbaru sudah mengaplikasikan teknologi EFI pada sistem bahan bakarnya. Melalui teknologi ini dapat dimungkinkan konsumsi bahan bakar, performa dan emisi yang lebih baik.

Dengan pengaplikasian teknologi yang semakin maju, kendaraan keluaran terbaru dapat memiliki performa yang lebih baik dibandingkan dengan kendaraan keluaran lama, apabila dikaitkan dengan konsumsi bahan bakar yang digunakan dan daya yang dapat dihasilkan. Sebagai contoh sepeda motor dari pabrikan yang sama dengan kapasitas silinder yang sama namun dengan teknologi yang lebih maju, dapat menghasilkan daya yang lebih besar seperti yang ditunjukkan pada tabel di bawah.

Tabel 1. Perbandingan Daya Mesin Sepeda Motor yang Mengaplikasikan Karburator dengan EFI

\begin{tabular}{lll}
\hline Sistem Bahan Bakar & Karburator & EFI \\
\hline Tipe Mesin & 4 langkah SOHC & 4 langkah SOHC \\
Kapasitas Silinder & $124,8 \mathrm{cc}$ & $124,8 \mathrm{cc}$ \\
Diameter x Langkah & $52.4 \times 57.9 \mathrm{~mm}$ & $52.4 \times 57.9 \mathrm{~mm}$ \\
Perbandingan Kompresi & $9,0: 1$ & $9.3: 1$ \\
Daya Maksimum & $9,3 \mathrm{PS} / 7.500 \mathrm{rpm}$ & $10.1 \mathrm{PS} / 8.000 \mathrm{rpm}$ \\
Torsi Maksimum & $1,03 \mathrm{kgf.m} / 4000 \mathrm{rpm}$ & $0.95 \mathrm{kgf.m} / 4.000 \mathrm{rpm}$ \\
\hline
\end{tabular}

Sumber: www.astramotor.co.id

Saat ini kendaraan dengan sistem bahan bakar konvensional (menggunakan karburator) masih diproduksi dan beroperasi dalam jumlah yang banyak. Berdasarkan tabel di atas, menimbulkan pertanyaan bagaimana cara untuk meningkatkan performa (daya) mesin sepeda motor yang masih menggunakan sistem bahan bakar karburator atau sepeda motor keluaran lama sehingga dapat memiliki performa yang lebih baik? Untuk meningkatkan performa dari mesin sepeda motor yang masih standar diperlukan modifikasi dari sistem yang ada pada mesin yang dapat mempengaruhi kualitas proses pembakaran. Sistem tersebut diantaranya adalah sistem induksi udara, sistem mekanik mesin, sistem bahan bakar, sistem pembuangan, dan sistem pengapian. Intinya supaya pembakaran dapat terjadi dengan sempurna, harus terpenuhi syarat baik secara kualitas maupun kuatitas dari bahan bakar, udara dan panas. Oleh karena itu, untuk mendapatkan hasil yang maksimal diperlukan modifikasi yang menyeluruh karena dari masing-masing sistem tersebut saling terkait. Namun pada penelitian ini modifikasi hanya dilakukan pada beberapa aspek diantaranya, (a) volume mesin (cc); (b) perbandingan kompresi mesin; (c) mekanikal katup; (d) sistem pemasukan 
(intake); (e) sistem pembuangan (exhaust). Hal ini disebabkan karena sistem bahan bakar dan pengapian sudah baik.

Modifikasi yang dilakukan harus memperhatikan konstruksi dasar dan analisis dari sistem yang akan dimodifikasi, sehingga modifikasi yang dilakukan lebih realistis untuk dilaksanakan dan mampu meningkatkan daya mesin secara signifikan. Namun dengan emisi gas buang yang memenuhi regulasi yang telah ditetapkan.

Volume Mesin dan Tekanan Kompresi

Sistem mekanik mesin memiliki peranan yang sangat penting dalam menentukan besarnya daya yang dapat dihasilkan oleh mesin itu sendiri. Oleh karena itu dalam melakukan modifikasi mesin maka sistem mekanik dari mesin tidak dapat diabaikan apabila ingin mendapatkan performa yang maksimal. Dimana hal dasar yang dapat berpengaruh terhadap besar kecilnya daya yang dapat dihasilkan oleh mesin adalah kapasitas silinder (sering disebut cc, volume langkah, piston displacement), di mana semakin besar kapasitas silinder maka jumlah campuran bahan bakar dengan udara yang dapat ditampung untuk diledakkan juga semakin besar. Maka daya yang dapt dihasilkan juga akan semakin besar. Namun hal ini tidak mutlak karena proses pemasukan udara dan bahan bakar ke dalam mesin sangat dipengaruhi oleh kerja dari sistem yang lain. Kapasitas silinder dari mesin dapat dihitung dengan rumus berikut:
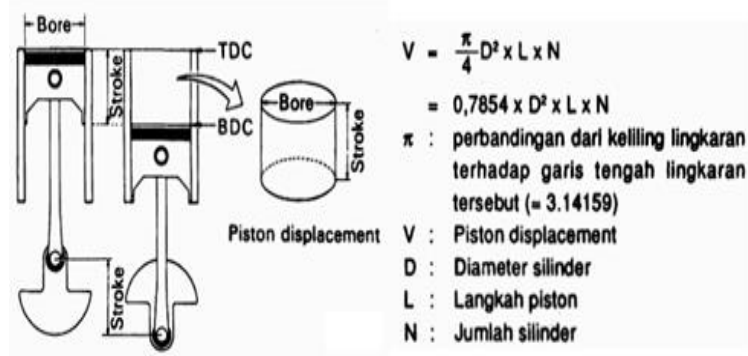

Sumber: PT. Toyota Astra Motor (New Step 1)

Gambar 1. Konstruksi Mekanisme Piston dan Rumus Menghitung Kapasitas Silinder

Berdasarkan rumus di atas, kapasitas silinder dipengaruhi oleh diameter silinder (bore) dan langkah piston (stroke), dimana dengan kapasitas yang sama desain dari silinder dapat dibuat berbeda. Desain dari silinder ini akan menentukan daya dan karakter dari mesin, sehingga biasanya desainnya ditentukan atau dipertimbangkan dari aspek peruntukan mesin atau karakteristik mesin yang diinginkan.

Terdapat tiga jenis desain dari silinder yaitu desain long stroke, square, dan short stroke. Desain long stroke biasanya digunakan pada mesin yang dibutuhkan torsinya, namun dengan desain seperti ini rpm maksimum yang dapat dicapai relatif rendah jika dibandingkan dengan 2 desain silinder yang lainnya. Desain square memiliki dimensi stroke dan bore yang sama, dimana pada desain ini mencari karakteristik mesin yang memiliki torsi dan kecepatan yang seimbang. Desain short stroke memiliki dimensi ukuran bore yang lebih tinggi jika dibandingkan dengan panjang langkah dari piston. Mesin dengan desain silinder seperti ini diperuntukkan untuk mesin yang mengutamakan kecepatan atau diutamakan untuk dapat meraih rpm yang tinggi.

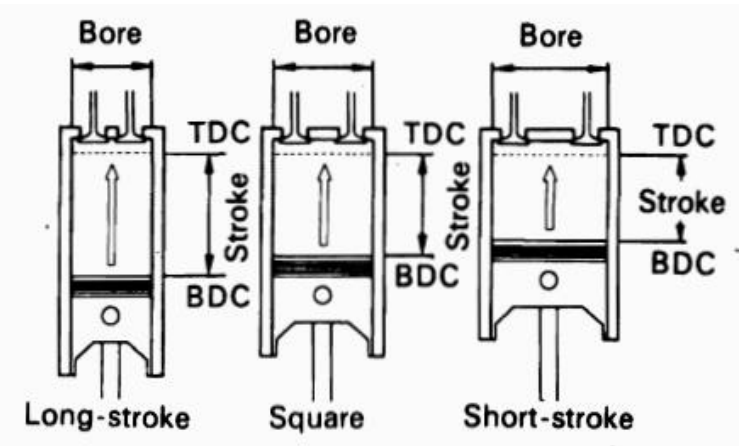

Sumber: PT. Toyota Astra Motor (New Step 1)

Gambar 2. Jenis Desain Silinder

Faktor yang tidak kalah penting yang mempengaruhi daya mesin adalah tekanan kompresi. Semakin tinggi tekanan kompresi maka panas yang dapat dibangkitkan untuk proses penguapan bahan bakar sehingga lebih mudah bercampur atau bereaksi dengan udara menjadi lebih mudah. Namun karena bahan bakar bensin memiliki nilai ketahanan terhadap kompresi atau tekanan (nilai oktan) yang terbatas maka tekanan kompresi akan efektif sampai titik tertentu tergantung dari kondisi bahan bakar yang digunakan. 
Ukuran yang biasanya digunakan untuk menginterpretasikan besarnya tekanan kompresi adalah dengan perbandingan kompresi. Perbandingan kompresi menunjukkan berapa jauh campuran bahan bakar dengan udara yang dihisap selama langkah hisap dikompresikan dalam silinder selama langkah kompresi. Dengan kata lain, perbandingan dari silinder dengan volume ruang bakar dengan torak pada posisi TMB $\left(\mathrm{V}_{2}\right)$ dengan volume ruang bakar dengan torak TMA $\left(\mathrm{V}_{1}\right)$. Rumus lebih jelasnya untuk menghitung perbandingan kompresi adalah sebagai berikut:

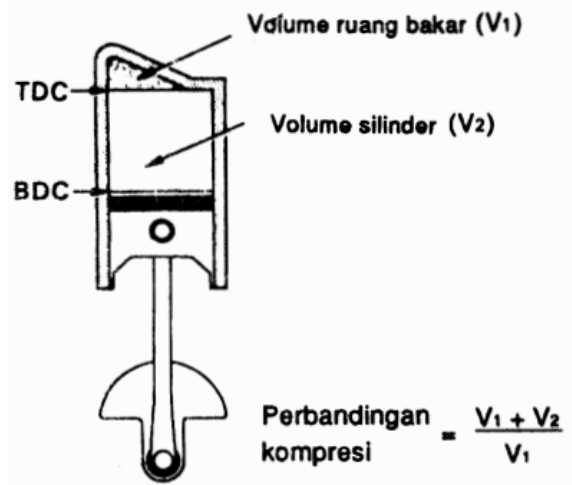

Sumber: PT. Toyota Astra Motor (New Step 1)

Gambar 3. Cara Menghitung Perbandingan Kompresi

\section{Sistem Mekanikal Katup}

Katup pada mesin berfungsi untuk menutup dan membuka saluran masuk (intake) dan buang (exhaust) yang berhubungan dengan ruang bakar. Bentuk mekanisme katup mengalami kemajuan seiiring dengan berkembangnya teknologi. Revolusi bentuk mekanisme katup dapat dilihat pada gambar di bawah.

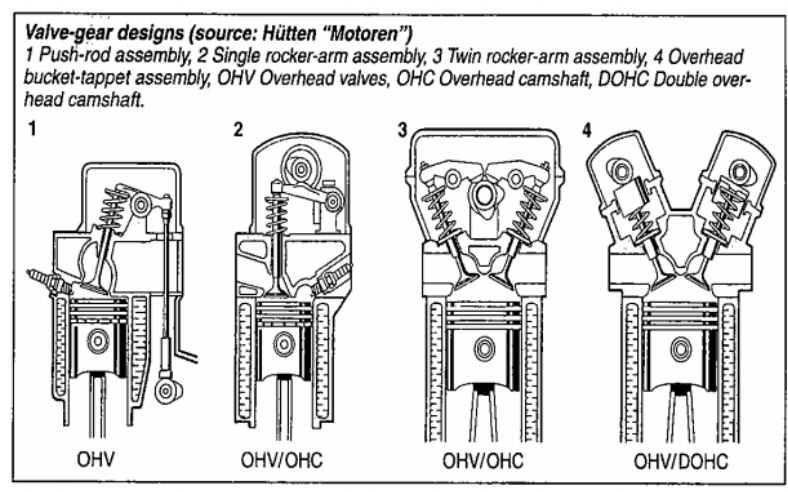

Sumber: Bosch (2000: 408)

Gambar 4. Jenis Mekanisme Katup
Pengembangan pada mekanisme katup bertujuan untuk mengefektifkan kerja katup sehingga lebih minim gesekan, responsif dalam pembukaan dan saat menutup, dan mampu memfasilitasi untuk aliran yang maksimal dari fluida yang melewatinya. Jenis keempat dari mekanisme katup pada gambar di atas adalah yang paling canggih dan dapat memberikan performa yang maksimal. Jenis tersebut memiliki dua buah camshaft sehingga terdapat dua buah katup masuk dan dua buah katup buang dalam satu silinder. Dengan kondisi ini maka saluran masuk maupun buang dari silinder menjadi lebih besar dan mendukung untuk tercapainya efisiensi volumetrik yang lebih baik.

Kerja dari katup berkontribusi terhadap kualitas tahapan kerja dari mesin 4 langkah. Dimana ukuran katup (port) berpengaruh terhadap daya mesin yang dapat dihasilkan. Ukuran katup yang lebih besar akan menyebabkan udara dapat mengalir ke dalam silinder dengan lebih maksimal (Heywood, J. B., 1988: 220) karena hambatan fluida yang melaluinya semakin kecil. Selain ukuran yang menjadi parameter yang mempengaruhi besar daya atau performa mesin adalah timing dan lama bukaan katup. Mekanisme yang mengatur timing membuka dan menutupnya katup adalah camshaft. Pada camshaft terdapat nok yang akan menyebabkan katup terbuka dan menutup dengan bantuan pegas katup.

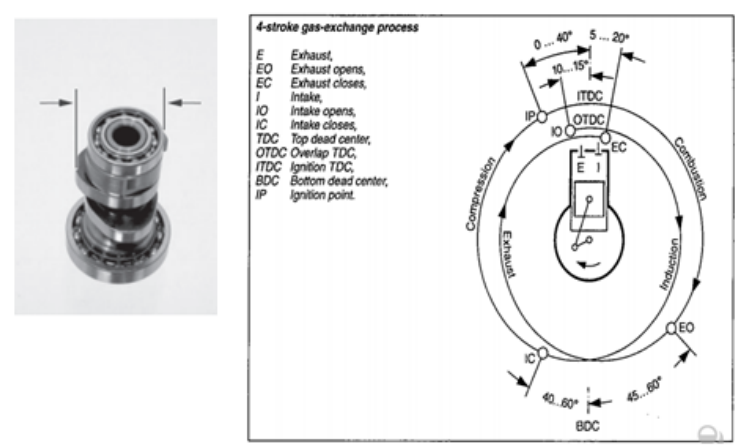

Sumber: Bosch (2000: 385)

Gambar 5. Camshaft Sepeda Motor dan Siklus Kerja Katup

Bentuk dan dimensi dari nok pada camshaft akan mempengaruhi lamanya bukaan katub dan timingnya. Dimana untuk 
memperoleh efisiensi volumetrik yang tinggi maka timing dan lamanya bukaan katup harus tepat. Selain itu dimensi dan bentuk dari katup akan berpengaruh pada karakteristik dari mesin. Untuk mesin yang digunakan untuk keperluan balap maka akan disetting supaya dapat menghaasilkan efisiensi volumetrik yang sebesar mungkin dengan memaksimalkan lama bukaan katup untuk katup masuk maupun katub buang.

Sistem Induksi Udara/ Sistem Pemasukan Udara

Sistem pemasukan udara yang terdiri dari filter udara, karburator, katup throttle, intake manifold, intake port, katup masuk, dapat memberikan hambatan kepada udara yang masuk ke dalam silinder. Parameter yang digunakan untuk mengukur efektifitas dari proses induksi udara adalah efisiensi volumetrik. Efisiensi volumetrik ini hanya berlaku pada motor 4 langkah yang memiliki proses induksi udara yang jelas. Rumus yang digunakan untuk menghitung efisiensi volumetrik menurut Heywood, J. B. (1988: 54) sebagai berikut:

$$
\eta_{v}=\frac{m_{a}}{\rho_{a, i} V_{d}}
$$

Dari rumus tersebut, efisiensi volumetrik adalah perbandingan antara massa udara sebenarnya yang masuk ke silinder dengan ukuran massa ideal dari udara yang seharusnya dapat masuk ke dalam silinder. Oleh karena itu nilai maksimal yang dapat dicapai oleh mesin dengan sistem induksi atau pemasukan udara secara alami tanpa adanya supercharger atau turbocharger adalah 1 .

Untuk meningkatkan efisiensi volumetrik dari mesin maka perlu adanya modifikasi dari sistem induksi udara yang ada baik dari saluran masuk pertama yaitu filter udara sampai dengan gerbang terakhir yaitu katup. Bentuk dan ukuran saluran perlu disesuaikan dengan kapasitas mesin yang ada sehingga mampu melewatkan udara dengan kapasitas volume udara yang sesuai dengan hambatan yang sekecil mungkin. Kelengkungan dari saluran juga perlu dipertimbangakan karena semakin besar kelengkungan dari saluran maka akan menyebabkan hambatan dari saluran menjadi besar.

Selain itu hal yang menjadi faktor penghambat adalah tingkat kehalusan dari saluran, saluran yang kasar dapat menyebabkan adanya aliran turbulen dari fluida yang melewatinya sehingga hambatan yang terjadi menjadi lebih besar. Namun pada bagian tertentu seperti intake manifold pada motor bensin dengan sistembahan bakar yang masih menggunakan karburator, kekasaran pada permukaan bagian dalam intake manifold bermanfaat untuk menghasilkan aliran turbulen sehingga akan membantu meningkatkan homogenitas campuran bahan bakar dengan udara. Oleh karena itu dalam menghaluskan bagian ini untuk meningkatkan efisiensi volumetrik perlu dipertimbangkan aspek atau komponen lain yang mampu membantu campuran bahan bakar dan udara yang masuk ke dalam silinder tetap homogen.

\section{Sistem Pembuangan}

Sistem pembuangan memiliki peranan penting dalam menyalurkan gas hasil pembakaran keluar, meredam suara mesin, dan mengurangi emisi gas buang (apabila dipasang catalitic converter). Konstruksi sistem pembuangan juga akan berpengaruh terhadap performa kendaraan. Sistem pembuangan baik yang meliputi exhaust manifold dan knalpot dapat memberikan hambatan pada laju keluarnya gas buang apabila ukurannya tidak sesuai (terlalu kecil) dan permukaan yang dilewati gas buang kasar permukaannya.

Oleh karena itu dalam melakukan modifikasi untuk meningkatkan performa maka aspek sistem pembuangan tidak dapat diabaikan. Perlu adanya penyesuaian untuk dapat mengakomodasi jumlah gas buang yang semakin banyak apabila terdapat kenaikan volume silinder. Selain itu konstruksi bentuk saluran harus memungkinkan untuk memberikan hambatan yang sekecil mungkin terhadap gas buang yang melewatinya baik dari 
bentuk saluran maupun tingkat kekasaran salurannya.

Daya mesin

Daya merupakan kecepatan usaha, artinya usaha per satuan waktu (Soenarta, N. \& Furuhama, S., 2002: 11). Rumus dari daya adalah sebagai berikut:

Keterangan:

$$
\mathbf{P}=\mathbf{W} / \mathbf{t}
$$

$$
\begin{array}{ll}
\mathrm{P} & \text { : Daya } \\
\mathrm{W} & \text { : Usaha } \\
\mathrm{T} & \text { : Waktu }
\end{array}
$$

Untuk mesin 4 langkah Heywood, J. B. (1988: 57) merumuskan daya dengan persamaan sebagai berikut:

$$
P=\frac{\eta_{f} \eta_{v} N V_{d} Q_{\mathrm{Hv}} \rho_{a,(}(F / A)}{2}
$$

Rumus tersebut diperoleh dari penggabungan persamaan untuk efisiensi volumetrik, rasio perbndingan campuran bahan bakar dengan udara, rata-rata tekanan efektif dan efisiensi konversi bahan bakar. Daya digunakan sebagai indikator performa dari mesin, mesin yang sanggup menghasilkandayayang besar dapat dikatan mesin tersebut memiliki performa yang baik. Heywood, J. B. (1988: 57) menyatakan terdapat paling tidak 5 hal yang dapat mempengaruhi performa dari mesin diantaranya sebagai berikut, (a) Dari sisi bahan bakar, bahan bakar memiliki efisiensi konversi yang tinggi; (b) Mesin memiliki efisiensi volumetrik yang tinggi, (c) Meningkatkan output yang diberikan oleh gerakan mesin dengan meningkatkan massa jenis udara yang masuk; (d) Rasio campuran bahan bakar dengan udara yang sesuai sehingga dapat terbakar dengan maksimum di dalam silinder; (e) Rata-rata kecepatan piston yang tinggi.

Karakteristik dari daya mesin yang dihasilkan adalah cenderung semakin meningkat seiring dengan naiknya putaran mesin. Namun untuk momen yang dihasilkan berbentuk grafik parabolik yaitu momen akan meningkat sampai titik maksimum kemudian menurun seiring dengan naiknya putaran mesin seperti yang ditampilkan pada gambar di bawah.

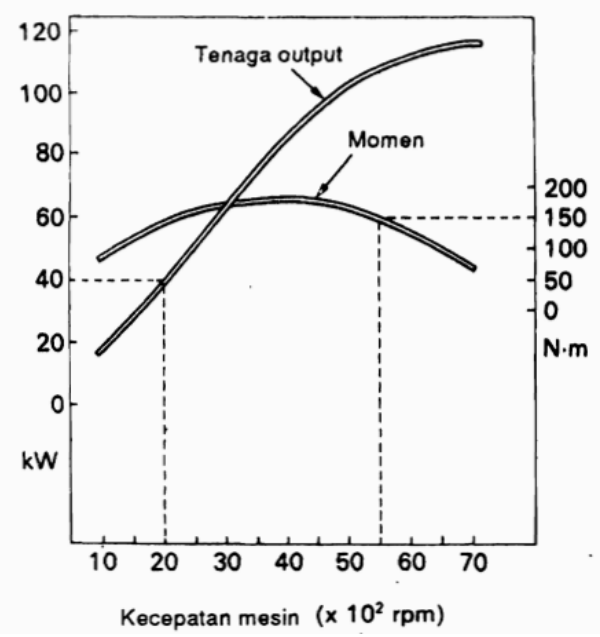

Gambar 6. Kurva Kemampuan Mesin

\section{Emisi Gas Buang Motor Bensin}

Setiap motor bakar akan menghasilkan emisi gas buang. Proses pembakaran yang sempurna akan menghasilkan karbon dioksida $\left(\mathrm{CO}_{2}\right)$ dan uap air $\left(\mathrm{H}_{2} \mathrm{O}\right)$ namun untuk mencapai hal tersebut bukan sesuatu yang mudah karena banyak sekali faktor yang berpengaruh. Ketersediaan komponen utama pembakaran diantaranya adalah udara, bahan bakar dan panas dalam komposisi yang tepat dan waktu pembakaran yang cukup merupakan salah satu kunci untuk menghasilkan pembakaran yang sempurna. Apabila proses pembakaran tidak terjadi dengan baik, maka akan menghasilkan emisi gas buang yang beberapa di antaranya berbahaya bagi kesehatan manusia dan dapat merusak lingkungan. Berikut merupakan emisi yang dapat dihasilkan oleh motor bensin (Zainal Arifin dan Sukoco, 2009: 35), (a) Carbon Monoxida (CO), secara keseluruhan kandungan $\mathrm{CO}$ di udara terdiri dari $11 \%$ dari emisi motor diesel dan $89 \%$ merupakan emisi dari motor bensin. CO terbentuk karena adanya bahan bakar yang terbakar tidak sempurna karena kekurangan oksigen; (b) Hydro Carbon (HC), HC merupakan emisi gas buang yang terjadi karena adanya bahan bakar yang tidak terbakar; (c) Nitrogen Oxide (NOx), emisi ini biasanya berbentuk $\mathrm{NO}, \mathrm{NO}_{2}$, dan $\mathrm{N}_{2} \mathrm{O}$. Gas- 
gas tersebut terbentuk karena temperatur pembakaran yang tinggi sehingga nitrogen dan oksigen bereaksi.

Hubungan antara nilai lamda dengan torsi yang dihasilkan mesin dan hubungannya dengan emisi gas buang yang dihasilkan disajikan pada grafik di bawah.

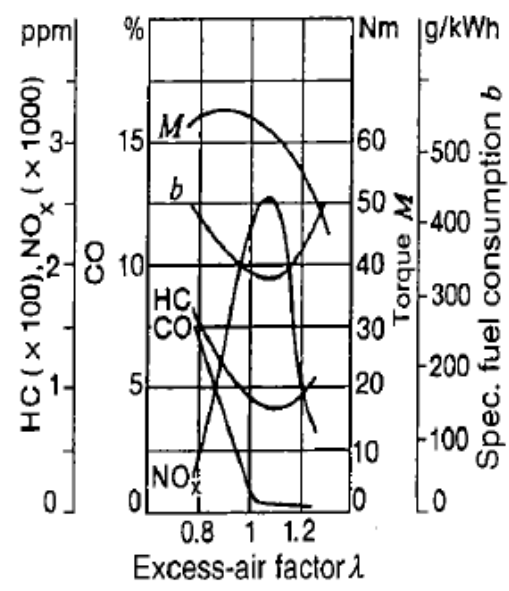

Sumber: Bosch (2000: 518)

Gambar 7. Hubungan antara lamda dengan emisi gas buang dan torsi

Di Indonesia emisi gas buang kendaraan lama diatur melalui Peraturan Menteri Negara Lingkungan Hidup, No. 05 Tahun 2006 tentang Ambang Batas Emisi Gas Buang Kendaraan Bermotor Lama. Dimana parameter yang digunakan adalah tahun pembuatan dan emisi gas buang yang digunakan sebagai acuan adalah $\mathrm{CO}$ dan HC. Untuk lebih jelasnya ambang batas yang ditetapkan adalah sebagai berikut.

Tabel 2. Ambang Batas Emisi Sepeda Motor

\begin{tabular}{ccccc}
\hline \multirow{2}{*}{ Kategori } & \multirow{2}{*}{$\begin{array}{c}\text { Tahun } \\
\text { Pembuatan }\end{array}$} & $\begin{array}{c}\mathrm{CO} \\
(\%)\end{array}$ & $\begin{array}{c}\mathrm{HC} \\
(\mathrm{ppm})\end{array}$ & $\begin{array}{c}\text { Metode } \\
\text { Uji }\end{array}$ \\
\hline $\begin{array}{l}\text { Sepeda Motor } \\
\text { langkah }\end{array}$ & $<2010$ & 4,5 & 12000 & Idel \\
$\begin{array}{l}\text { Sepeda Motor } 2 \\
\text { langkah }\end{array}$ & $<2010$ & 5,5 & 2400 & Idel \\
$\begin{array}{l}\text { Sepeda Motor }(2 \\
\text { dan 4 langkah }\end{array}$ & $\geq 2010$ & 4,5 & 2000 & Idel \\
\hline
\end{tabular}

\section{METODE PENELITIAN}

Jenis Penelitian

Penelitian ini menggunakan metode penelitian research and development. Melalui metode ini dapat digali konsep modifikasi yang harus dilakukan untuk meningkatkan daya secara maksimal namun emisi gas buang masih memenuhi ambang batas yang ditetapkan pemerintah pada mesin sepeda motor 4 langkah dengan sistem bahan bakar karburator..

Subjek Penelitian

Sumber data atau subjek penelitian ini adalah mesin sepeda motor 4 langkah dengan sistem bahan bakar karburator dengan spesifikasi sebagai berikut:

Tabel 3. Spesifikasi standar mesin yang digunakan

\begin{tabular}{ll}
\hline \multicolumn{1}{c}{ Aspek } & \multicolumn{1}{c}{ Spesifikasi } \\
\hline Jenis Mesin & 4 langkah 1 silinder \\
Sistem bahan bakar & Karburator \\
Kapasitas Silinder & $102 \mathrm{cc}$ \\
Diameter Silinder x Langkah & $49 \times 54 \mathrm{~mm}$ \\
Rasio Kompresi & $9.0: 1$ \\
Pendingin & Udara \\
Daya Maksimum & $8,2 \mathrm{HP} / 8000 \mathrm{rpm}$ \\
Torsi Maksimum & $8,65 \mathrm{Nm} / 6500 \mathrm{rpm}$ \\
Sistem Pengapian & CDI AC \\
\hline
\end{tabular}

Metode dan Instrumen Pengumpulan Data

Alat yang digunakan untuk mengumpulkan data daya mesin adalah dynotest, sedangkan exhaust gas analzser digunakan untuk mengumpulkan data emisi gas buang. Lembar dokumentasi digunakan untuk mengumpulkan dan mendokumentasikan data dari hasil uji tersebut serta mendokumentasikan data spesifikasi awal kendaraan dan setelah dimodifikasi. Untuk menjamin pengontrolan terhadap variabel yang dapat menjadikan hasil penelitian bias maka digunakan lembar kontrol pengujian untuk membantu peneliti melaksanakan pengontrolan ketika pengujian dilaksanakan

\section{Prosedur Pengembangan}

Analisis

Pengembangan konsep modifikasi pada mesin motor ini diawali dengan mengumpulkan data awal mesin yang akan dimodifikasi baik dari spesifikasi, konstruksi mesin serta daya awal mesin sebelum modifikasi. Berdasarkan data 
tersebut kemudian dianalisis kelemahan dari sistem mesin dan hasil pengujian awal mesin sehingga dapat ditentukan sistem dan bentuk modifikasi yang akan dilakukan untuk mendapatkan daya yang maksimal namun emisi gas buang masih memenuhi ambang batas yang ditetapkan pemerintah.

Desain

Berdasarkan analisis yang telah dilakukan, maka dibuat desain rancangan dari setiap sistem yang perlu dilakukan modifikasi. Secara teoritis semua sistem saling terkait, sehingga untuk melakukan modifikasi pada suatu sistem maka diperlukan penyesuaian pada sistem yang lain untuk mendapatkan daya yang maksimal. Oleh karena itu, modifikasi akan dilakukan pada bagian atau aspek berikut:

Tabel 4. Sistem Pemasukan dan Pembuangan

\begin{tabular}{|c|c|c|}
\hline Aspek Modifikasi & Kondisi Awal & Modifikasi \\
\hline $\begin{array}{l}\text { Porting polish } \\
\text { saluaran intake }\end{array}$ & $16 \mathrm{ml}$ & $22,5 \mathrm{ml}$ \\
\hline $\begin{array}{l}\text { Porting polish } \\
\text { saluaran exhaust }\end{array}$ & $10 \mathrm{ml}$ & $13.5 \mathrm{ml}$ \\
\hline Muffler & $24 \mathrm{~mm}$ & $26 \mathrm{~mm}$ \\
\hline
\end{tabular}

\begin{tabular}{|c|c|c|}
\hline \multicolumn{3}{|c|}{$\begin{array}{c}\text { Tabel 5. Tekanan Kompresi dan Kapasitas } \\
\text { Silinder }\end{array}$} \\
\hline Aspek Modifikasi & Kondisi Awal & Modifikasi \\
\hline $\begin{array}{l}\text { Bentuk } \quad \text { Ruang } \\
\text { Bakar }\end{array}$ & Setengah Bola & Bathub \\
\hline Diameter piston & $48.985 \mathrm{~mm}$ & $55 \mathrm{~mm}$ \\
\hline Jenis piston & $\begin{array}{l}\text { Standar tanpa } \\
\text { coakan }\end{array}$ & $\begin{array}{l}\text { Forged Piston } \\
\text { dengan } \\
\text { coakan }\end{array}$ \\
\hline $\begin{array}{l}\text { Squish pada } \\
\text { Piston }\end{array}$ & Tidak ada & 8 derajat \\
\hline Rasio Kompresi & $9.0: 1$ & $11.4: 1$ \\
\hline Kapasitas Silinder & $102 \mathrm{cc}$ & $129.3 \mathrm{cc}$ \\
\hline
\end{tabular}

Tabel 6. Modifikasi Mekanikal Katup

\begin{tabular}{|c|c|c|}
\hline Aspek Modifikasi & Kondisi Awal & Modifikasi \\
\hline $\begin{array}{l}\text { Diameter Katup } \\
\text { Masuk }\end{array}$ & $22.9 \mathrm{~mm}$ & $26 \mathrm{~mm}$ \\
\hline $\begin{array}{l}\text { Diameter } \\
\text { Buang }\end{array}$ & $19.9 \mathrm{~mm}$ & $23 \mathrm{~mm}$ \\
\hline $\begin{array}{l}\text { Diameter Batang } \\
\text { katup }\end{array}$ & $4.5 \mathrm{~mm}$ & $5 \mathrm{~mm}$ \\
\hline $\begin{array}{l}\text { Tinggi Angkat } \\
\text { nok Masuk }\end{array}$ & $4.428 \mathrm{~mm}$ & $9,5 \mathrm{~mm}$ \\
\hline $\begin{array}{l}\text { Tinggi Angkat } \\
\text { nok Buang }\end{array}$ & $4.234 \mathrm{~mm}$ & $9,55 \mathrm{~mm}$ \\
\hline $\begin{array}{l}\text { Durasi membuka } \\
\text { Katup Masuk }\end{array}$ & $170^{\circ}$ & $275^{\circ}$ \\
\hline $\begin{array}{l}\text { Durasi membuka } \\
\text { Katup Buang }\end{array}$ & $176^{\circ}$ & $277^{\circ}$ \\
\hline Overlaping Katup & $70^{\circ}$ & $70^{\circ}$ \\
\hline
\end{tabular}

Implementasi

Melaksanakan modifikasi berdasarkan desain yang telah dirancang terhadap mesin sepeda motor 4 langkah dengan sistem bahan bakar karburator yang menjadi subjek penelitian.

Evaluasi

Untuk mengetahui daya mesin yang dapat dihasilkan setelah dilaksanakan modifikasi, maka dilakukan pengukuran daya mesin menggunakan dynotest dan emisi gas buang menggunakan exhaust gas analyser. Evaluasi dilakukan dari hasil pengukuran daya dan emisi gas buang, dan kemudian dilakukan koreksi atau perbaikan apabila ditemukan masalah atau kekurangan yang terjadi dalam modifikasi (seperti hasil pengujian yang kurang memuaskan). Untuk memperoleh hasil modifikasi mesin yang mampu menghasilkan daya maksimal dan emisi gas buang yang rendah.

\section{Teknik Analisis Data}

Data hasil pengujian dianalisis dengan statistik diskriptif berupa rata-rata dan persentase (\%) serta regresi sederhana. Selain itu data akan disajikan dengan menggunakan tabel dan grafik untuk didiskripsikan karakter mesin sebelum dan sesudah modifikasi.

\section{HASIL DAN PEMBAHASAN}

Daya Mesin

Besarnya daya mesin dari suatu motor bakar sangat dipengaruhi oleh kualitas pembakaran dalam silinder. Untuk meningkatkan daya mesin maka perlu dilakukan modifikasi supaya dapat meningkatkan kualitas pembakaran. Berikut merupakan data hasil pengujian daya sebelum modifikasi (kondisi standar) dan setelah modifikasi:

Daya mesin sebelum modifikasi

Sebelum dilakukan modifikasi kondisi mesin yang digunakan sudah tidak dapat menghasilkan tenaga seperti kondisi baru. 
Dimana dalam kondisi baru, daya dan torsi standar yang dapat dihasilkan oleh mesin adalah $8,2 \mathrm{HP} / 8000 \mathrm{rpm}$ dan $8,65 \mathrm{Nm} / 6500 \mathrm{rpm}$. Hasil pengujian awal mesin sebelum modiikasi, menggunakan alat dynotest mendapatkan data daya maksimum yang dapat dihasilkan sebesar 5,8 HP $/ 6063$ rpm sedangkan torsi maksimumnya adalah $8.07 \mathrm{Nm} / 4596 \mathrm{rpm}$.

Tabel 7. Hasil pengujian Daya dan Torsi sebelum modifikasi

\begin{tabular}{lcc} 
& Daya Maksimum & Torsi Maksimum \\
\hline Kondisi Baru/Spesifikasi Pabrik & $8,2 \mathrm{HP} / 8000 \mathrm{rpm}$ & $8,65 \mathrm{Nm} / 6500 \mathrm{rpm}$ \\
$\begin{array}{l}\text { Pengujian sebelum dilakukan } \\
\text { modifikasi }\end{array}$ & $5,8 \mathrm{HP} / 6063 \mathrm{rpm}$ & $8.07 \mathrm{Nm} / 4596 \mathrm{rpm}$ \\
\hline
\end{tabular}

Karakter daya yang dihasilkan mesin sebelum dimodifikasi dari putaran $2425 \mathrm{rpm}$ semakin meningkat seiiring dengan kenaikan putaran mesin, dari 4,6 HP sampai dengan puncaknya yaitu pada 5,8 HP pada $6063 \mathrm{rpm}$. Kemudian daya menurun sampai dengan 4.7 HP pada $7500 \mathrm{rpm}$ dan meningkat kembali sampai dengan 5.7 HP pada putaran $8000 \mathrm{rpm}$. Setelah itu daya yang dihasilkan mesin semakin menurun seiring dengan kenaikan rpm mesin.

Karakter torsi yang dihasilkan mesin sebelum dilakukan modifikasi adalah torsi semakin meningkat dari putaran $2425 \mathrm{rpm}$ dengan $7.29 \mathrm{Nm}$ sampai putaran $4596 \mathrm{rpm}$ dengan torsi $8.07 \mathrm{Nm}$. Kemudian torsi semakin menurun seiring dengan kenaikan putaran mesin. Untuk lebih jelasnya karakteristik daya dan torsi yang dihasilkan mesin sebelum dilakukan modifikasi dapat dilihat pada gambar di bawah.

\section{Daya Mesin Setelah Modifikasi}

Setelah dilakukan modifikasi pada mesin, diperoleh data pengujian dimana daya dan torsi yang dihasilkan mesin meningkat. Selain itu karakteristik daya dan torsi yang dihasilkan mesin juga berbeda dengan kondisi sebelum modifikasi (dapat dilihat dari grafik daya dan torsi yang dihasilkan mesin). Mesin dapat mencapai rpm yang lebih tinggi, yang sebelumnya hanya mencapai angka $8700 \mathrm{rpm}$ setelah dimodifikasi mampu mencapai rpm maksimum sebesar $11.250 \mathrm{rpm}$.

Tabel 8. Hasil Pengujian Daya dan Torsi Sebelum Modifikasi

\begin{tabular}{lcc}
\hline & Daya Maksimum & Torsi Maksimum \\
\hline Kondisi Setelah Modifikasi & $14,6 \mathrm{HP} / 10.171 \mathrm{rpm}$ & $11.37 \mathrm{Nm} / 8383 \mathrm{rpm}$
\end{tabular}

Karakter dari mesin setelah modifikasi yaitu mampu menghasilkan tenaga yang besar pada rpm yang tinggi. Dimana semakin tinggi rpm maka daya dan torsi yang dihasilkan semakin besar, setelah itu daya dan torsi menurun setelah mencapai titik maksimum seiring dengan kenaikan putaran mesin. 


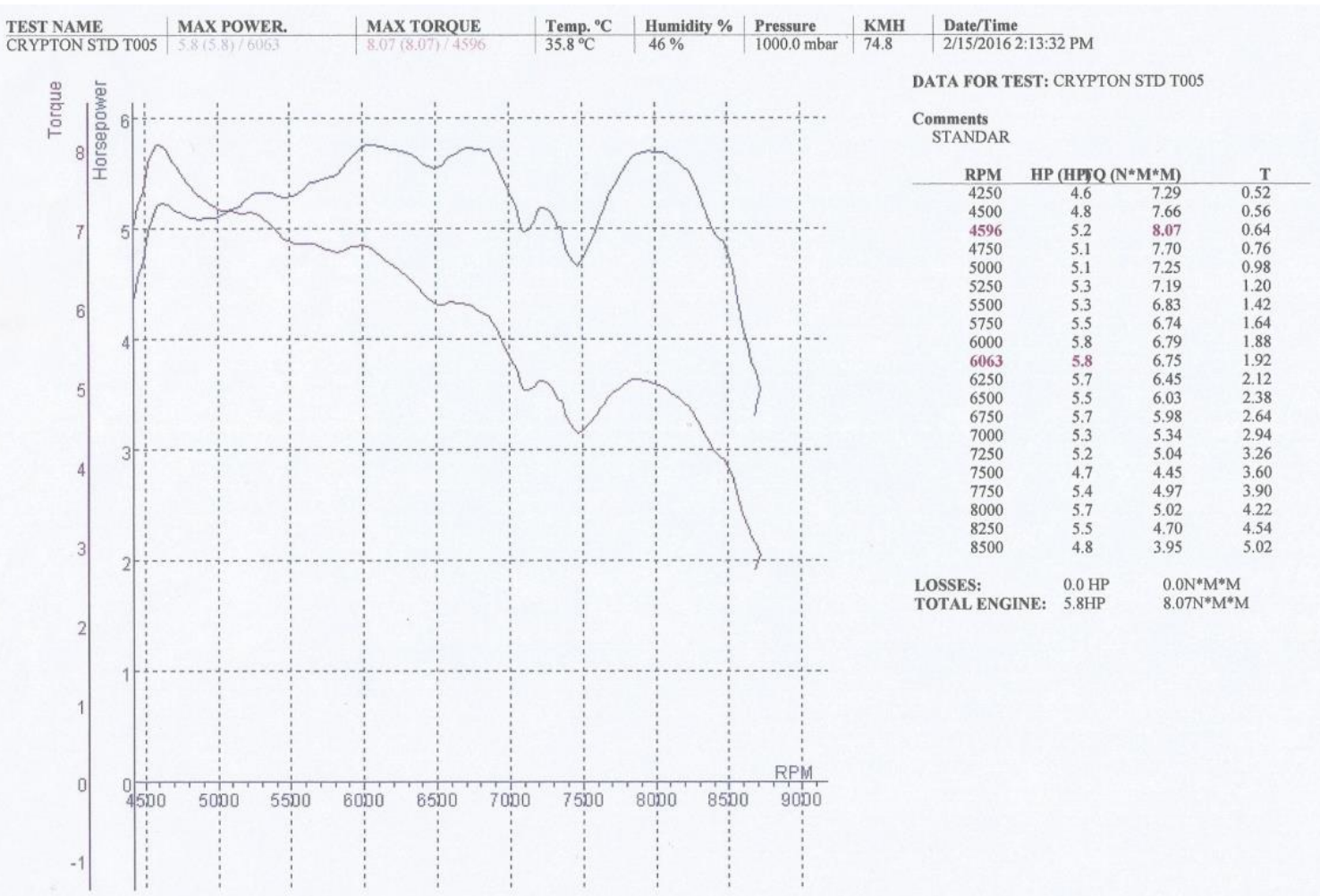

Gambar 8. Hasil Pengukuran Daya Sebelum Modifikasi

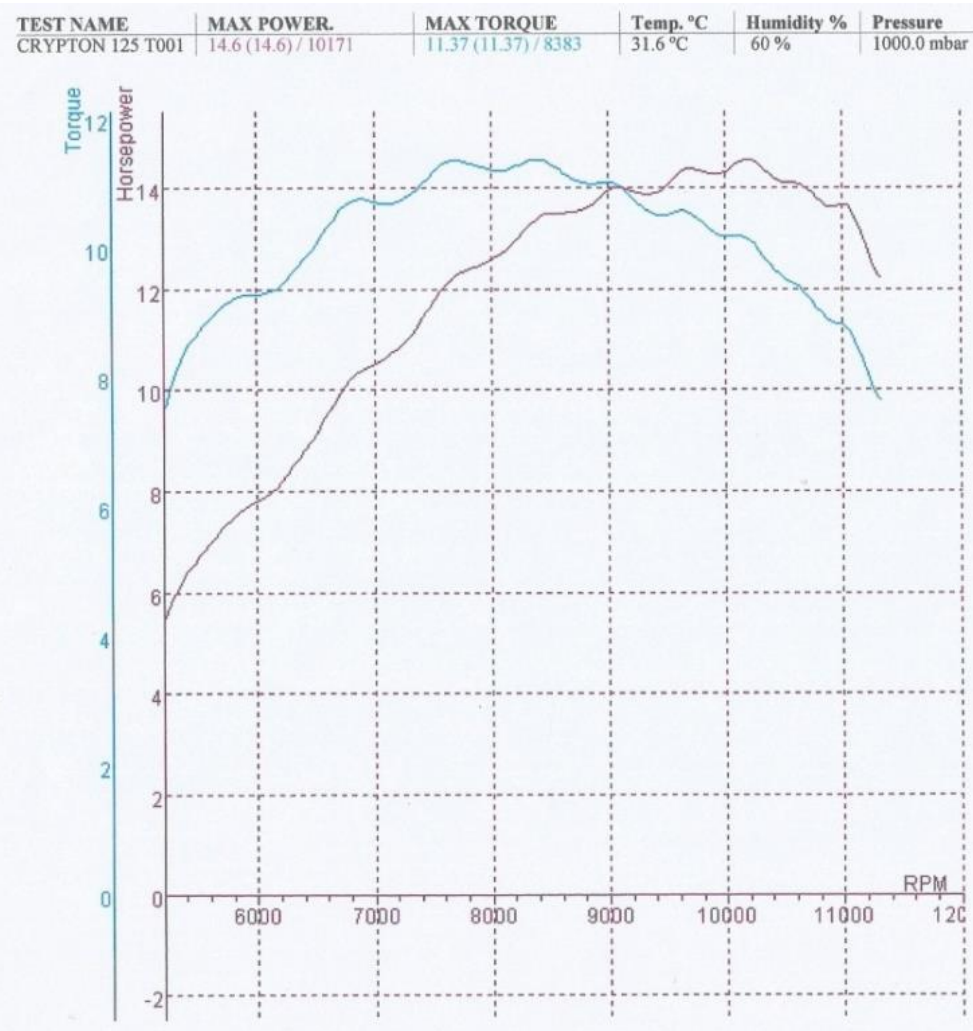

\begin{tabular}{l|l} 
KMH & Date/Time \\
\hline 83.1 & $5 / 24 / 20164: 18: 49$ PM
\end{tabular}

DATA FOR TEST: CRYPTON 125 T001

Comments

\begin{tabular}{cccc} 
RPM & HP $($ HPF & $\left(\mathbf{N}^{*} \mathbf{M}^{*} \mathbf{M}\right)$ & $\mathbf{T}$ \\
\hline 5000 & 5.8 & 7.86 & 0.52 \\
5250 & 6.0 & 8.08 & 0.54 \\
5500 & 6.7 & 8.73 & 0.64 \\
5750 & 7.4 & 9.18 & 0.76 \\
6000 & 7.8 & 9.29 & 0.88 \\
6250 & 8.3 & 9.53 & 0.98 \\
6500 & 9.2 & 10.07 & 1.08 \\
6750 & 10.1 & 10.66 & 1.18 \\
7000 & 10.6 & 10.71 & 1.30 \\
7250 & 10.9 & 10.77 & 1.38 \\
7500 & 11.8 & 11.19 & 1.48 \\
7750 & 12.3 & 11.34 & 1.58 \\
8000 & 12.6 & 11.21 & 1.68 \\
8250 & 13.1 & 11.32 & 1.78 \\
8383 & 13.4 & 11.37 & 1.82 \\
8500 & 13.5 & 11.28 & 1.88 \\
8750 & 13.6 & 11.01 & 1.98 \\
9000 & 14.0 & 11.01 & 2.08 \\
9250 & 13.9 & 10.69 & 2.18 \\
9500 & 14.1 & 10.54 & 2.30 \\
9750 & 14.4 & 10.45 & 2.40 \\
10000 & 14.3 & 10.18 & 2.50 \\
10171 & 14.6 & 10.17 & 2.58 \\
10250 & 14.5 & 10.05 & 2.62 \\
10500 & 14.1 & 9.52 & 2.74 \\
10750 & 13.8 & 9.07 & 2.88 \\
11000 & 13.7 & 8.80 & 3.00 \\
11250 & 12.4 & 7.78 & 3.16 \\
& & & \\
LOSSES: & $0.0 \mathrm{HP}$ & $0.0 \mathrm{~N}^{*} \mathrm{M}^{*} \mathrm{M}$ \\
TOTAL ENGINE: & $14.6 \mathrm{HP}$ & $11.37 \mathrm{~N}^{*} \mathrm{M}^{*} \mathrm{M}$
\end{tabular}

Gambar 9. Hasil Pengukuran Daya Setelah Modifikasi 
Modifikasi dilakukan pada beberapa bagian mesin yang meliputi a) volume mesin (cc); b) perbandingan kompresi mesin; c) mekanikal katup; d) sistem pemasukan (intake); e) sistem pembuangan (exhaust). Modifikasi yang dilakukan merupakan variabel bebas dan daya mesin merupakan variabel terikat dalam penelitian ini. Untuk mengetahui besaran nilai modifikasi yang perlu dilakukan untuk mendapatkan nilai daya yang diinginkan maka dilakukan regresi sederhana dari masingmasing variabel bebas dengan variabel terikat.

\section{Volume Mesin (cc)}

Peningkatan volume mesin dari 102 menjadi 129,3 cc berakibat meningkatnya jumlah bahan bakar dan udara yang dapat dibakar di dalam silinder. Hal ini akan menyebabkan naiknya daya yang dapat dihasilkan oleh mesin. Namun hal ini tidak mutlak, apabila tidak didukung oleh optimalisasi sistem-sistem yang lain. Untuk mendapatkan nilai daya yang dibutuhkan, maka nilai volume silinder dapat dihitung dengan persamaan $\mathrm{y}=0,322 \mathrm{x}-27,07$ seperti yang ditunjukkan pada grafik di bawah.

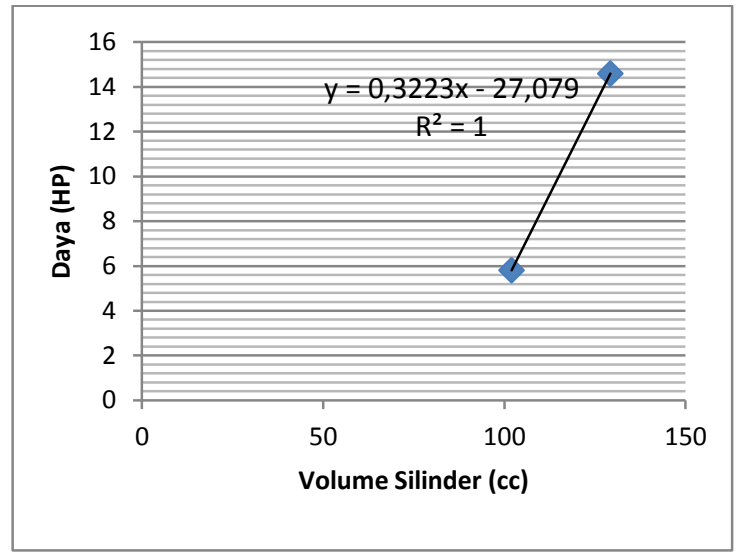

Gambar 10. Grafik Volume Silinder terhadap Daya

Perbandingan kompresi mesin

Perbandingan kompresi mesin pada penelitian ini ditingkatkan dari 1:9 menjadi 1 : 11,4 dengan tujuan dapat mengoptimalkan daya yang dihasilkan tapi sesuai dengan bahan bakar pertamax. Untuk mendapatkan nilai daya yang dibutuhkan, maka nilai perbandingan kompresi dapat dihitung dengan persamaan $\mathrm{y}=3,666 \mathrm{x}-$ 27,2 seperti yang ditunjukkan pada grafik di bawah.

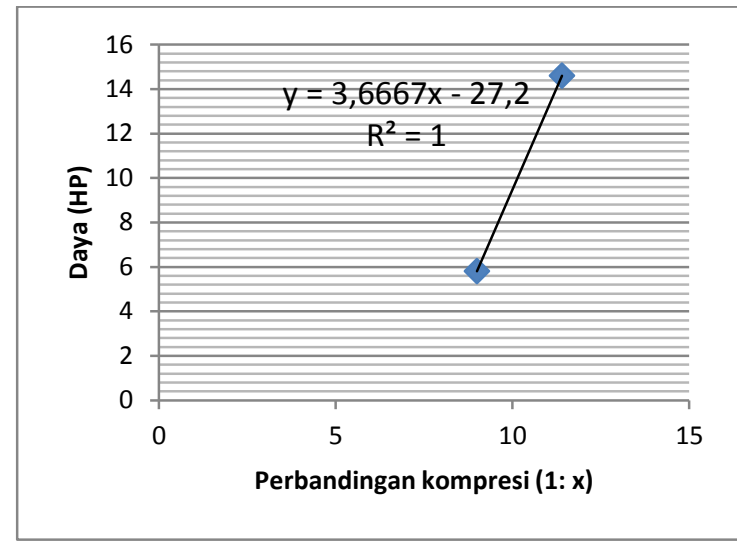

\section{Gambar 11. Grafik Perbandingan Kompresi terhadap Daya}

Modifikasi dilakukan pada beberapa bagian mesin yang meliputi a) volume mesin (cc); b) perbandingan kompresi mesin; c) mekanikal katup; d) sistem pemasukan (intake); e) sistem pembuangan (exhaust). Modifikasi yang dilakukan merupakan variabel bebas dan daya mesin merupakan variabel terikat dalam penelitian ini. Untuk mengetahui besaran nilai modifikasi yang perlu dilakukan untuk mendapatkan nilai daya yang diinginkan, dilakukan regresi sederhana dari masingmasing variabel bebas dengan variabel terikat.

Volume Mesin (cc)

Peningkatan volume mesin dari 102 menjadi 129,3 cc berakibat meningkatnya jumlah bahan bakar dan udara yang dapat dibakar di dalam silinder. Hal ini akan menyebabkan naiknya daya yang dapat dihasilkan oleh mesin. Namun hal ini tidak mutlak, apabila tidak didukung oleh optimalisasi sistem-sistem yang lain. Untuk mendapatkan nilai daya yang dibutuhkan, maka nilai volume silinder dapat dihitung dengan persamaan $\mathrm{y}=0,322 \mathrm{x}-27,07$ seperti yang ditunjukkan pada grafik di bawah. 


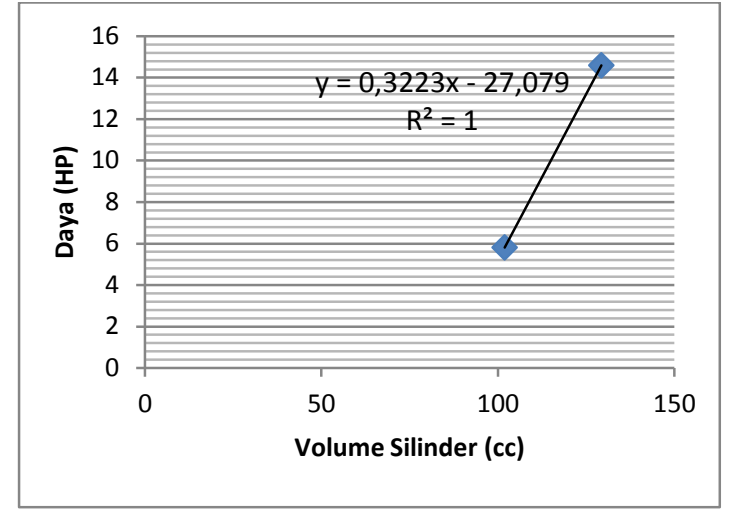

Gambar 12. Grafik Volume Silinder terhadap Daya

Perbandingan kompresi mesin

Perbandingan kompresi mesin pada penelitian ini ditingkatkan dari 1:9 menjadi 1 : 11,4 dengan tujuan dapat mengoptimalkan daya yang dihasilkan tapi sesuai dengan bahan bakar pertamax. Untuk mendapatkan nilai daya yang dibutuhkan, maka nilai perbandingan kompresi dapat dihitung dengan persamaan $\mathrm{y}=3,666 \mathrm{x}-$ 27,2 seperti yang ditunjukkan pada grafik di bawah.

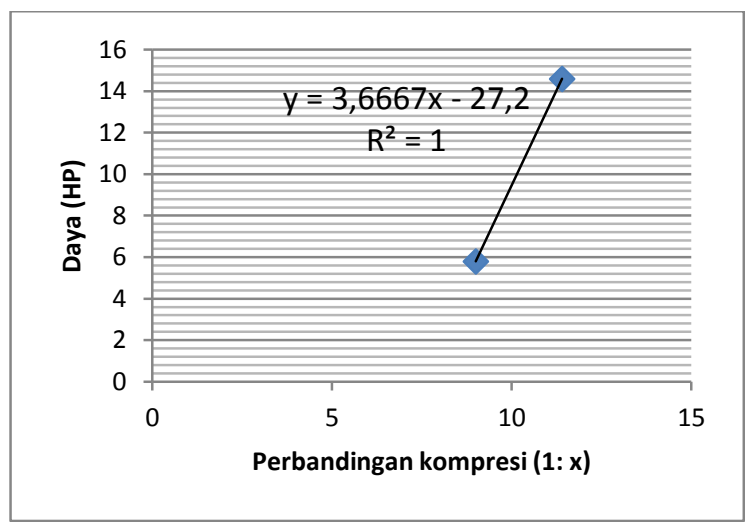

Gambar 13. Grafik Perbandingan Kompresi terhadap Daya

\section{Mekanikal katup}

Perbaikan atau modifikasi pada sisi mekanikal katup diantaranya adalah merubah tinggi angkat nok dan profil nok pada camshaft, sehingga akan mempengaruhi besarnya bukaan katup (menjadi lebih besar) dan durasi lama bukaan katup (menjadi lebih lama). Tujuannya adalah untuk mendapatkan daya yang diinginkan maka besarnya tinggi nok yang dibutuhkan dapat dihitung dengan persamaan berikut $y=1,735 x-1,882$, seperti yang tertera pada grafik di bawah.

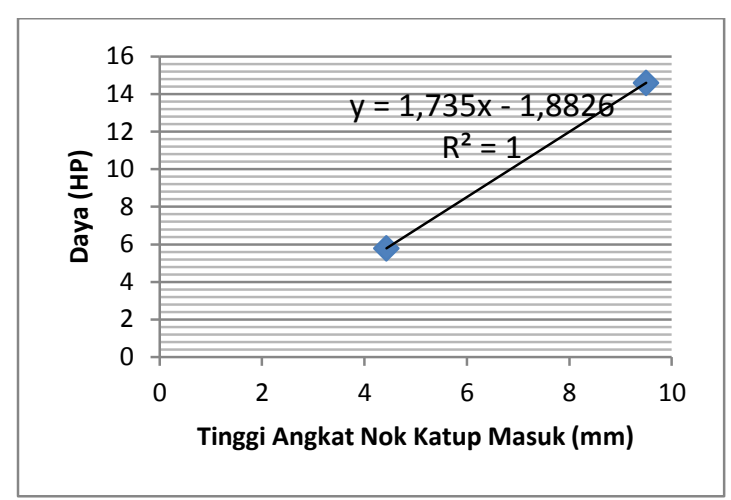

\section{Gambar 14. Grafik Tinggi Angkat Nok Katup} Masuk terhadap Daya

Pada aspek tinggi angkat nok katup masuk (intake) terjadi perubahan dari tinggi angkat nok sebelumnya sebesar $4.428 \mathrm{~mm}$ menjadi $9,5 \mathrm{~mm}$. Tentunya dengan adanya perubahan tinggi angkat nok maka perlu ada penyesuaian pada beberapa komponen lainnya seperti katup dan bentuk piston sehingga dengan perubahan tinggi angkat nok yang lebih dari 2 kali lipat tidak menyebabkan piston dan katup berbenturan.

Tinggi angkat nok katup buang dimodifikasi dengan tinggi awal $4.234 \mathrm{~mm}$ menjadi $9,55 \mathrm{~mm}$. Hal ini akan menyebabkan bukaan katup buang menjadi lebih besar sehingga dapat memaksimalkan proses pembilasan dan pembuangan gas hasil pembakaran. Untuk mendapatkan nilai daya yang diinginkan maka besarnya tinggi nok katup buang yang dibutuhkan dapat dihitung dengan persamaan berikut $\mathrm{y}=1,655 \mathrm{x}-1,208$, seperti yang tertera pada grafik di bawah. Untuk meningkatkan efisiensi pemasukan campuran bahan bakar dan udara ke dalam silinder serta mengurangi hambatan pada proses pengeluaran gas buang dan meningkatkan efektifitas proses pembilasan saat terjadi overlaping katup. 


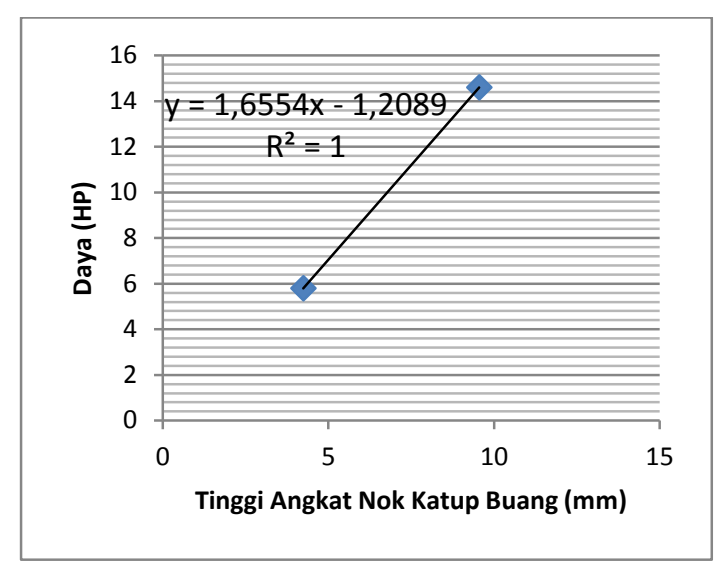

Gambar 15. Grafik Tinggi Angkat Nok Katup Buang terhadap Daya

Durasi kerja katup masuk dan buang menjadi lebih besar dan overlaping katup juga jadi lebih besar apabila dibandingkan dengan kondisi sebelum modifikasi. Diagram kerja katup pada mesin, sebelum dan sesudah modifikasi dapat dilihat pada diagram di bawah.
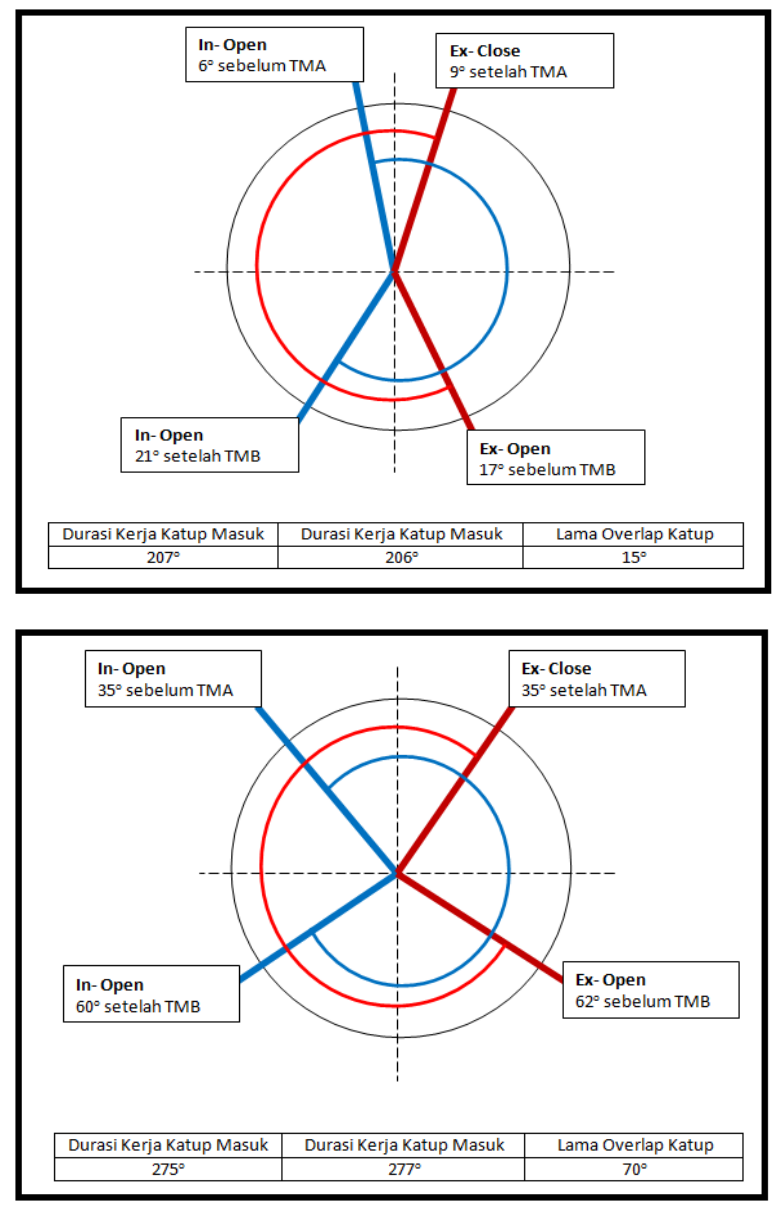

Gambar 16. Diagram Kerja Katup Sebelum (Atas) dan Sesudah (Bawah) Modifikasi
Sistem pemasukan (intake)

Daya yang maksimal dapat didapat salah satunya dengan memaksimalkan sistem pemasukan, di mana pada penelitian ini dilakukan modifikasi sistem pemasukan berupa porting dan polish untuk memperbesar dan memperhalus permukaan dari saluran masuk (intake). Volume saluran masuk dirubah dari 16 ml menjadi 22,5 $\mathrm{ml}$, sehingga dengan kondisi ini akan memungkinkan pemasukan campuran bahan bakar dan udara ke dalam silinder yang lebih banyak atau dapat meningkatkan angka randomen volumetrik. Selain itu dengan melakukan penghalusan saluran masuk (intake), hal ini akan mengurangi tahanan fluida yang masuk ke dalam silinder.

Untuk mendapatkan nilai daya yang diinginkan maka volume intake manifold yang dibutuhkan dapat dihitung dengan persamaan berikut $y=1,353 x-15,8$, seperti yang tertera pada grafik di bawah.

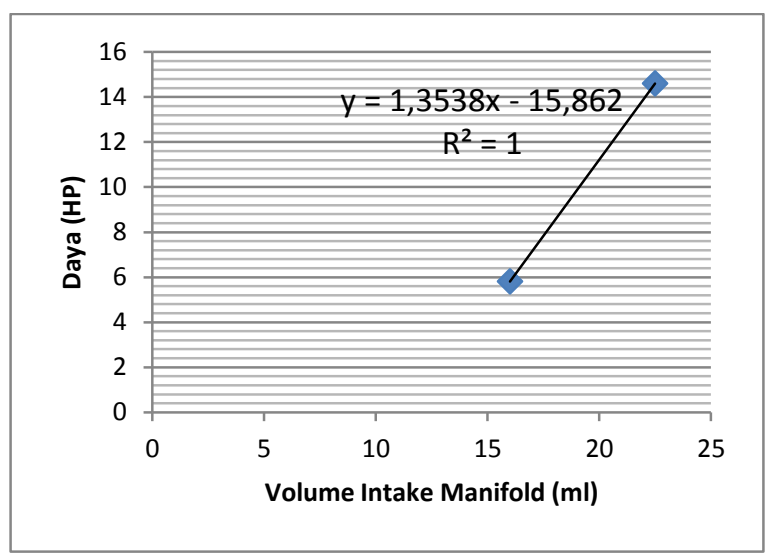

Gambar 17. Grafik Volume Intake Manifold terhadap Daya

Selain adanya modifikasi pada saluran intake, katup masuk juga dimodifikasi dengan menggunakan katup dengan diameter yang lebih besar sehingga memungkinkan untuk pemasukan campuran udara dan bahan bakar yang lebih baik. Pada aspek ini dilakukan penggantian ukuran katup dari 22,9 mm menjadi $26 \mathrm{~mm}$, dimana untuk mendapatkan nilai daya yang diinginkan maka diameter katup masuk yang dibutuhkan dapat dihitung dengan persamaan berikut $y=2,838 x-59,2$, seperti yang tertera pada grafik di bawah. 


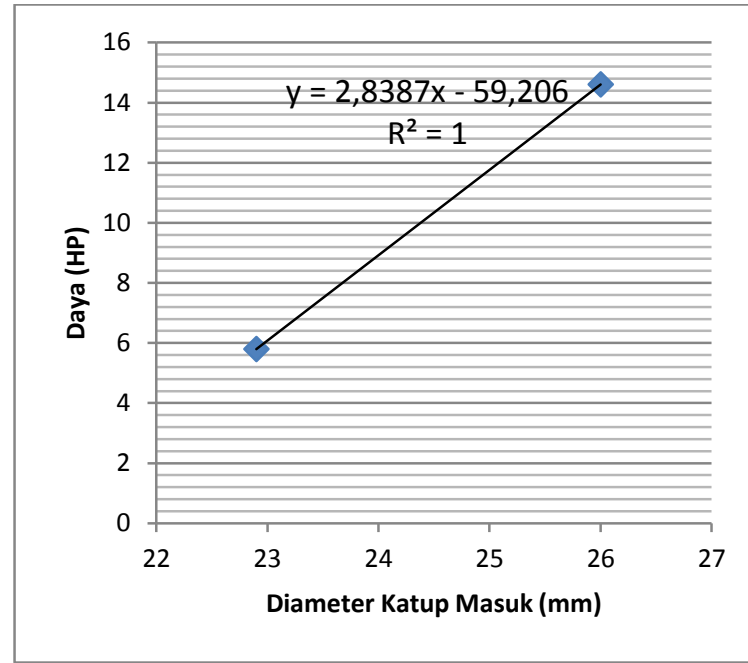

Gambar 18. Grafik Diameter Katup Masuk terhadap Daya

Sistem pembuangan (exhaust)

Sistem pembuangan pada mesin 4 langkah memiliki pengaruh yang cukup besar dalam kaitannya dengan daya yang dapat dihasilkan oleh mesin. Melalui sistem pembuangan yang baik, maka proses pembuangan gas sisa pembuangan menjadi lebih lancar sehingga sisa gas buang tidak tertinggal di ruang bakar. Dimana kondisi ini akan mempengaruhi proses pembakaran selanjutnya, semakin banyak gas sisa pembakaran yang tertinggal di dalam ruang bakar/silinder maka kualitas pembakaran akan semakin menurun.

Dimana dalam sistem mesin yang digunakan untuk penelitian, terdapat tiga bagian penting dalam sistem pembuangan diantaranya adalah katup buang, exhaust manifold dan muffler. Ketiga bagian tersebut, dimodifikasi dengan memperbesar diameter katup, melakukan porting polish pada exhaust manifold dan mengganti muffler yang memiliki diameter lebih besar. Intinya modifikasi pada ketiga komponen ini bertujuan untuk mengurangi hambatan dari gas buang yang keluar.

Katup buang dilakukan penggantian dari ukuran 19,9 mm menjadi $23 \mathrm{~mm}$, dimana untuk mendapatkan nilai daya yang diinginkan maka diameter katup buang yang dibutuhkan dapat dihitung dengan persamaan berikut $\mathrm{y}=$
$2,838 \mathrm{x}-50,69$, seperti yang tertera pada grafik di bawah.

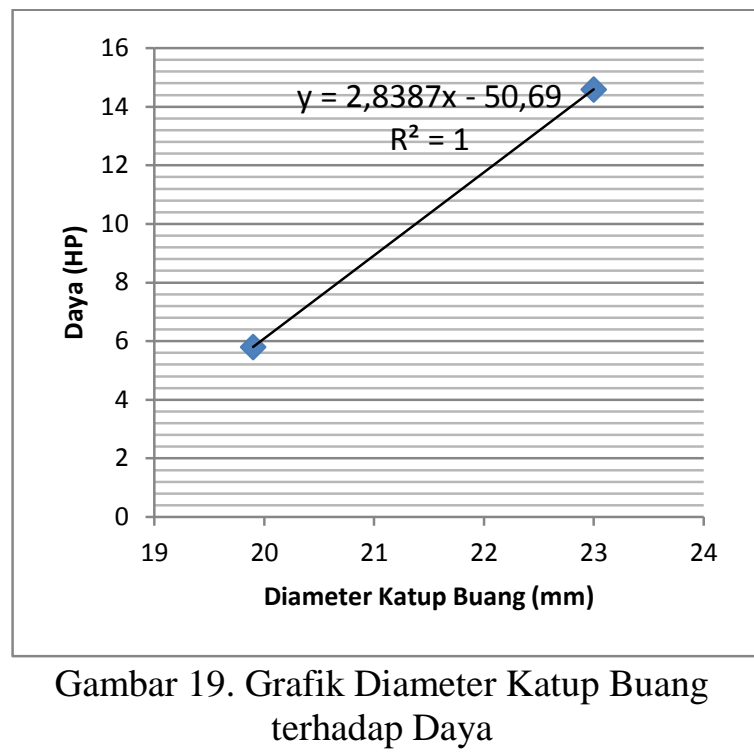

Modifikasi melalui proses porting polish dilakukan untuk mendapatkan permukaan saluran buang menjadi lebih halus dan diameternya lebih besar sehingga mampu melewatkan gas buang yang lebih banyak. Dengan modifikasi tersebut, volume exhaust manifold dirubah dari $10 \mathrm{ml}$ menjadi $13,5 \mathrm{ml}$. Untuk mendapatkan nilai daya yang diinginkan maka volume exhaust manifold yang dibutuhkan dapat dihitung dengan persamaan berikut $\mathrm{y}=2,514 \mathrm{x}-19,34$, seperti yang tertera pada grafik di bawah.

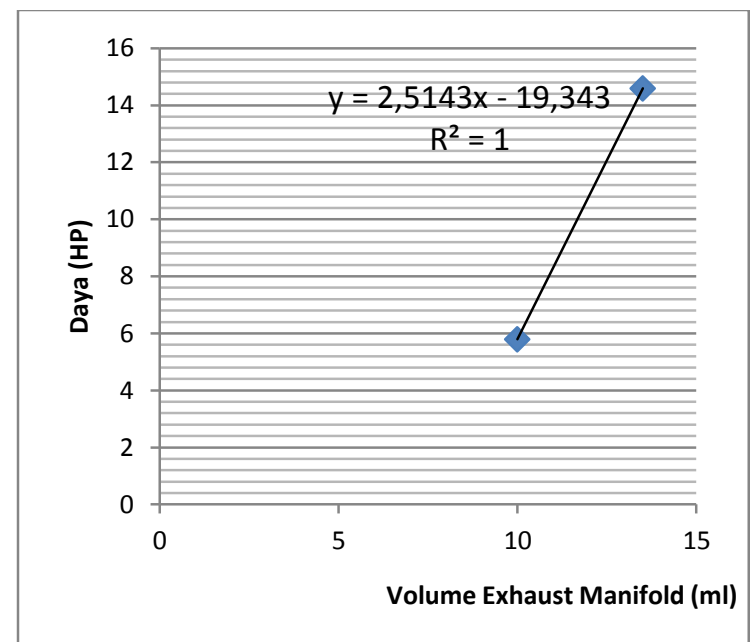

Gambar 20. Grafik Volume Exhaust Manifold terhadap Daya 
Untuk mengimbangi perubahan diameter exhaust manifold, maka juga dilakukan penggantian muffler dengan yang lebih besar yaitu dari $24 \mathrm{~mm}$ menjadi $26 \mathrm{~mm}$. Untuk mendapatkan nilai daya yang diinginkan maka volume exhaust manifold yang dibutuhkan dapat dihitung dengan persamaan berikut $\mathrm{y}=$ $4,4 x-99,8$, seperti yang tertera pada grafik di bawah.

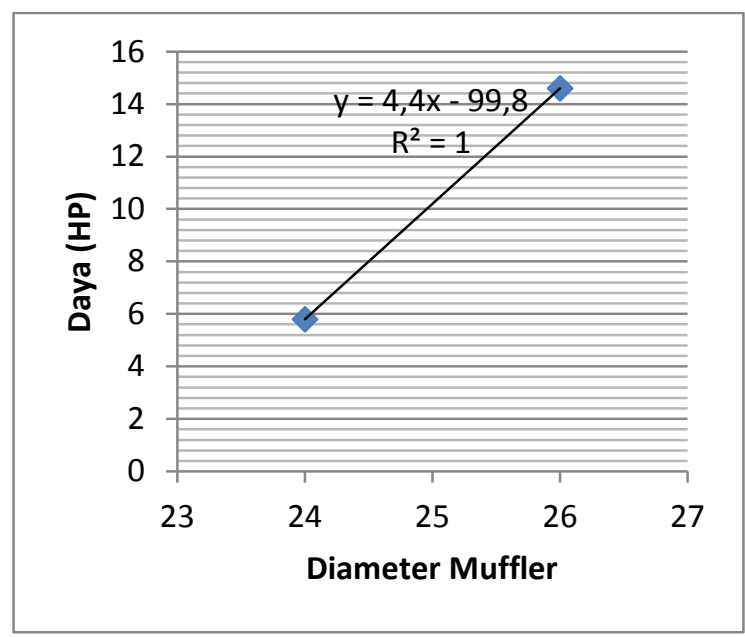

Gambar 21. Grafik Diameter Muffler terhadap Daya

Emisi Gas Buang

Emisi gas buang merupakan salah satu parameter penting dalam pengujian mesin sepeda motor. Salah satunya hasil pengujian tersebut dapat dijadikan acuan kinerja dari mesin. Dimana setiap kendaraan bermotor harus memenuhi ambang batas emisi gas buang yang ditetapkan oleh pemerintah. Oleh karena itu hasil modifikasi pada mesin juga tidak boleh menghasilkan emisi yang melebihi ambang batas walaupun tenaga yang dihasilkan menjadi lebih besar.

Berdasarkan hasil pengujian mesin yang dijadikan objek penelitian, menunjukkan ratarata hasil uji emisi seperti yang ditunjukkan pada tabel di bawah. Apabila dibandingkan dengan ambang batas emisi gas buang kendaraan yang merujuk pada Peraturan Menteri Negara Lingkungan Hidup, No. 05 Tahun 2006 tentang Ambang Batas Emisi Gas Buang Kendaraan Bermotor Lama. Baik pada emisi gas buang berupa $\mathrm{HC}$ dan $\mathrm{CO}$ masih memenuhi standar.
Pemerintah telah mengeluarkan aturan yang berkaitan dengan batasan emisi bagi kendaraan yang beroperasi di Indonesia, baik untuk kendaraan baru maupun kendaraan lama. Oleh karena itu setiap kendaraan tidak boleh melebihi dari kriteria emisi yang telah ditetapkan. Berdasarkan hasil pengujian emisi, emisi gas buang mesin setelah modifikasi masih masuk ambang batas emisi yang ditetapkan oleh pemerintah. Namun demikian, untuk dapat mendapatkan emisi gas buang yang lebih baik diperlukan tambahan system control emisi.

Modifikasi mesin yang salah satunya adalah menambah volume silinder mengakibatkan emisi yang dihasilkan menjadi semakin tinggi. Selain itu ditambah dengan faktor lain, dimana untuk mendapatkan daya atau power yang maksimal setelan campuran bahan bakar berada pada lamda kurang dari 1 (campuran kaya). Hal ini menyebabkan emisi gas buang seperti $\mathrm{CO}$ dan $\mathrm{HC}$ cenderung lebih tinggi. Untuk emisi Nox dari mesin belum didapat hasilnya karena alat ukur yang digunakan tidak dapat mengukur kadar Nox pada gas buang.

Alat kontrol emisi yang utama untuk diterapkan pada mesin hasil modifikasi ini harus dapat meminimalisir adanya emisi CO dan HC. Sehingga dapat digunakan teknologi seperti air suction dan EGR (Exhaust Gas Recirculating), air suction digunakan untuk menambahkan oksigen atau udara ke saluran gas buang sehingga sisa bahan bakar yang belum terbakar karena kekurangan oksigen dapat terbakar dan mengurangi kadar emisi yang keluar ke udara bebas. Teknologi EGR prinsipnya untuk mensirkulasikan ulang gas buang untuk dapat dibakar kembali ke dalam silinder. Sehingga dapat membakar ulang gas buang yang belum terbakar secara sempurna dimana teknologi ini dapat menurunkan kadar Nox pada gas buang secara signifikan. Namun konsekuensi dari penerapan teknologi ini menjadikan daya yang dihasilkan mesin menjadi sedikit menurun.

Selain itu keterbatasan dari sistem mesin yang belum dikontrol secara elektronik menyebabkan emisi yang dihasilkan tidak dapat 
ditekan sampai rendah. Ketidakpresisian kerja terutama dari sistem bahan bakar, dimana jumlah bahan bakar yang masuk ke dalam silinder tidak dapat diatur dengan presisi karena sistem pada karburator masih menggunakan pengaturan secara mekanik.

Tabel 9. Hasil Uji Emisi Gas Buang

\begin{tabular}{|c|c|c|c|c|c|}
\hline No & $\begin{array}{l}\text { Komponen Emisi } \\
\text { Gas Buang }\end{array}$ & $\begin{array}{c}\text { Hasil } \\
\text { Pengujian }\end{array}$ & $\begin{array}{c}\text { Rata-rata Hasil } \\
\text { Pengujian }\end{array}$ & $\begin{array}{l}\text { Standar } \\
\text { Emisi }\end{array}$ & Keterangan \\
\hline \multirow[t]{3}{*}{1} & $\mathrm{CO}(\%)$ & 3,393 & 3,191 & 5.5 & Memenuhi Standar \\
\hline & & 2,874 & & & \\
\hline & & 3,306 & & & \\
\hline \multirow[t]{3}{*}{2} & $\mathrm{HC}(\mathrm{ppm})$ & 940 & 817 & 2400 & Memenuhi Standar \\
\hline & & 696 & & & \\
\hline & & 815 & & & \\
\hline
\end{tabular}

\section{SIMPULAN DAN SARAN}

Simpulan

Berdasarkan hasil pembahasan dapat ditarik beberapa kesimpulan diantaranya adalah sebagai berikut: (1) Modifikasi mesin yang meliputi a) volume mesin (cc); b) perbandingan kompresi mesin; c) mekanikal katup; d) sistem pemasukan (intake); e) sistem pembuangan (exhaust) dapat meningkatkan daya mesin sebesar $151 \%$ dari 5,8 HP/6063 rpm menjadi 14,6 HP/10.171 rpm; (2) Emisi gas buang mesin setelah modifikasi masih masuk dalam ambang batas emisi yang ditetapkan pemerintah yakni HC 817 ppm lebih rendah dari ambang batas 2400 ppm, dan CO 3,191\% lebih rendah dari ambang batas $5.5 \%$.

Saran

Berdasarkan simpulan dapat diajukan saran sebagai berikut: (1) Modifikasi mesin harus menyesuaikan penggunaan bahan bakar yang paling ideal untuk digunakan pada mesin tersebut; (2) Perlu adanya tambahan system control emisi pada kendaraan sehingga emisi yang dihasilkan lebih rendah lagi; (3) Perlu adanya penelitian lanjutan untuk mengetahui besarnya nilai peningkatan yang dihasilkan dari masing-masing system yang dimodifikasi pada mesin.

\section{Daftar Pustaka}

Astra Honda Motor. New Supra X 125. Diunduh pada 24 Maret 2016 darihttp://www.astramotor.co.id/motorhonda/supra-X-125

. New Supra X 125 FI. Diunduh pada 24 Maret 2016 darihttp://www.astrahonda.com/produk/kendaraan/new-suprax-125-fi/\#.VvSkrbIrLIU

Badan Pusat Statistik. Perkembangan Jumlah Kendaraan Bermotor menurut Jenis Tahun 1987-2013.Diunduh pada 24 Maret 2016 darihttp://www.bps.go.id/linkTabelStatis/ view/id/1413.

Bosch. (2000). Automotive Handbook $5^{\text {th }}$ Edition. Stuttgart: Robert Bosch GmbH.

Heywood, J. B. (1988). Internal Combustion Engine Fundamentals. New York: McGraw-Hill. Inch.

PT. Astra Honda Motor. (2002). Buku Pedoman Reparasi Honda Karisma. PT. Astra Honda Motor.

. (2002). Buku Pedoman Reparasi Honda Win. PT. Astra Internasional.

(tth). New Step 1 Training Manual. PT. Toyota Astra Motor.

Soenarta, N. \& Furuhama, S. (2002). Motor Serba Guna. Jakarta: Pradnya Paramita.

Zainal Arifin \& Sukoco. (2009). Pengendalian Polusi Kendaraan. Bandung: Alfabeta. 